ISSN : 2621-1475

Pengaruh Penambahan Daging Gurita, Yani et al.,

J. Fish Protech 2019, Vol. 2 No. 1

\title{
PENGARUH PENAMBAHAN DAGING GURITA (Octopus cyanea) TERHADAP NILAI ORGANOLEPTIK DAN KANDUNGAN PROKSIMAT STIK GURITA
}

\author{
Yani *, Moh. Nuh Ibrahim, Suwarjoyowirayatno \\ Jurusan Teknologi Hasil Perikanan Fakultas Perikanan dan Ilmu Kelautan Universitas Halu Oleo, \\ Jalan H.E.A Mokodompit Kampus Bumi Tridharma Anduonohu, Kendari 93232 Sulawesi Tenggara \\ Telepon +6282192325910 \\ *Korespondensi: yani0492018@gmail.com \\ Diterima: 12 Maret 2019/Disetujui: 28 Maret 2019
}

Cara sitasi: Cara sitasi: Yani, Ibrahim MN, Suwarjoyowirayatno. 2019. Pengaruh penambahan daging gurita (Octopus cyanea) terhadap nilai organoleptik dan kandungan proksimat stik gurita. Jurnal Fish Protech. 2(1): 18-26.

\begin{abstract}
Abstrak
Penelitian ini bertujuan untuk mengetahui pengaruh penambahan daging gurita terhadap nilai organoleptik, proksimat stik gurita. Metode penelitian ini menggunakan Rancangan Acak Lengkap (RAL) yang terdiri dari tiga perlakuan yaitu P1 (Daging gurita 35\%), P2 (Daging gurita 45\%), P3 (Daging gurita 55\%). Data hasil pengamatan dianalisa menggunakan ANOVA (Analysis of Variance) pada taraf 95\%, apabila terdapat beda nyata ( $>>0,05$ ) maka dilakukan uji lanjut dengan uji DMRT (Duncam Multiple Range Test) pada taraf nyata 95\%. Kandungan protein dan lemak diuji menggunakan metode AOAC dan kandungan karbohidrat di uji menggunakan metode nelson-smogiy. Hasil uji kandungan kadar lemak dan karbohidrat tertinggi terdapat pada perlakuan P1 dengan nilai 34,27\% dan $7,81 \%$ dan Kandungan protein tertinggi pada perlakuan P3 dengan nilai 32,04\%. Hasil penelitian ini menunjukan bahwa terdapat pengaruh nyata terhadap kandungan lemak dan karbohidrat serta tidak terdapat pengaruh nyata pada kandungan air dan protein pada stik gurita.
\end{abstract}

Kata kunci: Daging gurita (Octopus cyanea), stik gurita, kandungan proksimat, uji organoleptik

\section{THE EFFECT OF OCTOPUS (Octopus cyanea) MEAT ADDITION ON ORGANOLEPTIC VALUES AND PROXIMATE CONTENT OF OCTOPUS STICKS}

\begin{abstract}
This study aims to determine the effect Octopus cyanea addition on organoleptic values and proximate content of octopus sticks. This research method used a completely randomized design (CRD) consisting of three treatments P1 (35\% octopus meat), P2 (45\% octopus meat), P3 (55\% octopus meat). Observation data were analyzed using ANOVA (Analysis of Variance) at the level $95 \%$, if there were significant differences $(p>0,05)$ then further
\end{abstract}


testing was carried out with DMRT (Duncan Multiple Range Test) at 95\%. The content of protein and fat was tested by the AOAC method and the carbohydrate content was tested by the nelson-smogiy method. The highest test results for the content of fat and carbohydrate were found in treatment P1 with a value of $34.27 \%$ and $7.81 \%$ and the highest protein content found in treatment P3 with a value of $32.04 \%$. The results of this study indicated that there is a real effect on the content of fat and carbohydrates and there is no significant effect on the water content and protein of octopus sticks.

Key words: Octopus cyanea, octopus stick, proximate content, organoleptic value

\section{PENDAHULUAN}

Gurita memiliki potensi sumber daya laut yang menjadi komoditi unggulan bagi para nelayan dan pengusaha perikanan di Kota Kendari selain ikan tuna (Listiani, 2013). Berdasarkan hasil penelitian Fajriah (2015) diperoleh 15 komoditas unggulan yang menentukan keunggulan komparatif perikanan tangkap di Kota Kendari yakni gurita, layang, lemadang, beloso, sunglir, ikan pedang, setuhuk hitam, tongkol krai, cakalang, banyar, kenyar, tuna mata besar dan baronang kuning.

Mutu produk olahan gurita yang baik berasal dari mutu bahan mentah yang segar dan belum mengalami proses pembusukan, tetapi mutu produk olahan yang buruk berasal dari mutu bahan mentah yang tidak segar dan telah mengalami proses penguraian senyawasenyawa didalam tubuh gurita sehingga mutu olahan menjadi untuk memperpanjang turun, diperlukan pengolahan dan pengawetan untuk mencegah pembusukan (Adawiyah, 2008). Gurita merupakan spesies yang banyak terdapat di perairan Indonesia dan tercatat pemanfaatannya hanya dikeringkan dan diolah menjadi produk beku untuk tujuan ekspor. Indonesia menempati urutan ke- 4 setelah Cina, Jepang dan Korea sebagai pengekspor gurita di Asia, dengan total produksi gurita mencapai 17.080 ton (FAO, 2014).

Pemanfaatan gurita (Octopus cyenea) dalam berbagi produk misalnya pada kerupuk gurita, tepung gurita yang digunakan sebagai bahan baku pakan ikan dan minuman nutrisi olahraga berbasis hidrolisat protein gurita yang dapat dihasilkan dari hidrolisis protein gurita (Riyanto et al., 2016). Pemanfaatan gurita selain produk-produk kerupuk, bisa juga dibuat produk lain seperti stik dari gurita.

Stik merupakan makanan ringan yang berbahan dasar terigu yang memiliki kadar protein rendah. Protein berfungsi sebagai alat pembangun, mengganti jaringan yang rusak, dan mengatur 19etabolism tubuh (Poedjiadi, 2005). Kandungan protein yang cukup tinggi pada gurita (Octopus cyanea) dapat dimanfaatkan sebagai bahan untuk menambah kandungan gizi pada stik gurita (Octopus cyanea).

\section{BAHAN DAN METODE}

\section{Bahan dan Alat}

Bahan yang digunakan terdiri atas bahan utama dan bahan pendukung. Bahan utama adalah daging gurita segar. Bahan pendukung adalah tepung tapioka, merica, garam, margarine, jeruk nipis, air, telur, backing powder dan minyak 
goreng. Bahan untuk analisis proksimat adalah aquades, reagen biuret, larutan standar glukosa, larutan standar protein, petroleum eter, heksan, bovin serum albumin, $\mathrm{NaOH}$.

Peralatan yang digunakan dalam penelitian ini ada dua macam yaitu alat untuk pengolahan dan alat untuk analisis. Alat pengolahan meliputi: baskom, pisau, blender, cetakan, panci, kompor dan stopwatch. Alat untuk analisis proksimat meliputi: seperangkat alat ekstraksi soxle (iwaki), gelas piala (iwaki pyrex), gelas ukur(pyrex), batang pengaduk, pipet tetes (supertek), pipet mikro (toppette-nesco), corong (pyrex), tabung reaksi (pyrex), labu takar (pyrex),erlenmeyer (pyrex), desikator (equipment pharmacy), sentrifus (KORL-KLOP), timbangan analitik (M5-ION), gegep, cawan porselin (RRC), cawan aluminium (pyrex), botol semprot (Pudak).

\section{Rancangan Penelitian}

Penelitian ini menggunakan Rancangan Acak Lengkap (RAL) yang terdiri dari 3 perlakuan yaitu P1 (daging gurita $35 \%$ ), P2 (daging gurita $45 \%$ ), P3 (daging gurita $55 \%$ ) dengan penambahan tepung terigu $100 \mathrm{~g}$ dan tepung tapioka $50 \mathrm{~g}$. Masing-masing perlakuan dilakukan tiga kali ulangan, sehingga diperoleh jumlah satuan percobaan sebanyak 9 unit.

\section{Pembuatan Stik Gurita}

\section{Penyiapan Bahan}

Daging gurita yang digunakan pada pembuatan stik dibersihkan dengan cara memisahkan isi kepala, gigi, mata serta dibuka kulitnya dan dicuci sampai bersih dengan menggunakan air dan es. Daging gurita yang di ambil yaitu bagian lengannya. Kemudian ditambahkan perasaan jeruk nipis selama 3 menit lalu gurita dikukus dengan panci presto selama 15 menit. Daging gurita yang telah bersih dihaluskan (dilumatkan) menggunakan blender dan ditimbang sesuai dengan kebutuhan.

\section{Pembuatan Adonan}

ditimbang ${ }_{\text {kemudian }}^{\text {gurita yang sudah }}$ pencampuran adonan. Pembuatan adonan adalah pencampuran semua bahan hingga homogen. Tepung tapioka, daging gurita, bumbu yang sudah dihaluskan dan air dicampur dan diuli menggunakan tangan, pencampuran ini dilakukan selama 15 menit hingga terbentuk adonan yang homogen. Apabila adonan tersebut dipegang dengan tangan tidak lengket, menunjukkan pengadonan telah cukup.

\section{Pencetakan}

Setelah proses pembuatan adonan selesai, adonan stik dicetak dengan ukuran panjamg $8 \mathrm{~cm}$.

\section{Penggorengan}

Penggorengan dilakukan dengan menggunakan minyak panas dengan api yang kecil. Minyak yang telah panas kemudian adonan stik yang telah dicetak dimasukan. Suhu selama penggorengan digoreng dengan suhu selama $120{ }^{\circ} \mathrm{C}$. Stik gurita tersebut telah matang dan dapat diangkat apabila stik gurita tersebut telah berwarna agak kecoklatan.

\section{Penirisan}

Penirisan merupakan suatu cara yang dilakukan untuk mengurangi minyak yang terkandung dalam bahan sebelum dikemas. Penirisan dilakukan pada tempat yang kering dan tidak lembab. Proses penirisan dilakukan sampai produk dingin. 


\section{Analisis Data}

Untuk mengetahui pengaruh perlakuan terhadap parameter yang diamati maka dilakukan analisis ragam ANOVA (Analisis of Variance). Jika terdapat pengaruh nyata maka akan dilanjutkan dengan uji DMRT (Duncan Multiple Range Test) pada tingkat kepercayaan $95 \% \quad(\alpha=0,05) \quad$ untuk menentukan tiap-tiap perlakuan (Steel and Storrie, 1993).

\section{HASIL DAN PEMBAHASAN}

Rekapitulasi hasil analisis ragam (uji F) terhadap uji organoleptik dan kimia stik dengan penambahan daging gurita (Octopus cyanea) yang berbeda dapat dilihat pada Tabel 1 berikut.

Tabel 1. Rekapitulasi analisis ragam uji sensori dan kimia stik dengan penambahan daging gurita (Octopus cyanea) yang berbeda.

\begin{tabular}{lccc}
\hline & \multicolumn{3}{c}{ Perlakuan } \\
\cline { 2 - 4 } Parameter & P1 & P2 & P3 \\
\hline Uji Sensori & & $7,4 \pm 1,4$ & $7,2 \pm 1,07$ \\
Warna & $7,5 \pm 1,06$ & $7,4 \pm 0,61$ & $7,9 \pm 0,97$ \\
Aroma & $7,3 \pm 0,61$ & $7,0 \pm 1,18^{\mathrm{ab}}$ & $7,6 \pm 1,16^{\mathrm{bc}}$ \\
Rasa & $6,9 \pm 1,75^{\mathrm{a}}$ & $6,8 \pm 1,23$ & $6,6 \pm 1,29$ \\
Tekstur & $6,9 \pm 1,24$ & & \\
\hline Uji Kimia & & $30,87 \pm 1,01$ & $32,04 \pm 3,64$ \\
Kadar Protein & $30,88 \pm 3,63$ & $33,08 \pm 1,59^{\mathrm{b}}$ & $28,14 \pm 1,59^{\mathrm{bc}}$ \\
Kadar Lemak & $34,27 \pm 0,67^{\mathrm{a}}$ & $5,97 \pm 0,54^{\mathrm{ab}}$ & $5,54 \pm 1,31^{\mathrm{c}}$ \\
Kadar Karbohidrat & $7,8 \pm 1,31^{\mathrm{a}}$ & & \\
\hline
\end{tabular}

Keterangan : Notasi yang sama menunjukan perbedaan tidak nyata pada taraf kepercayaan $95 \%$

\section{Uji Sensori}

Warna stik dengan penambahan daging gurita menunjukkan nilai tertinggi pada perlakuan P1 (DG 35\%) sebesar 7,4 dan nilai terendah pada perlakuan P3 (DG $55 \%$ ) sebesar 7,1. Warna stik pada penelitian ini lebih tinggi dari warna tertinggi produk stik ikan nilem dari hasil penelitian (Iqbal et al.,2016) yaitu 7,2\% dengan penambahan daging ikan nilem $15 \%$.Hal ini diduga dengan penambahan tepung lebih banyak dibandingkan dengan daging gurita menghasilkan stik berwarna kecoklatan. Sesuai dengan penelitian Natalia et al. (2018) bahwa penambahan tepung tapioka lebih banyak dibandingkan daging gurita dapat meningkatkan warna kecoklatan pada krupuk gurita. Penelitian ini didukung oleh Winarno (2004) yang menyatakan bahwa produk stik yang memiliki warna coklat disebabkan adanya reaksi Maillard (reaksi-reaksi antara karbohidrat, khususnya gula pereduksi dengan gugus amina primer yang terdapatpada bahan sehingga menghasilkan bahan berwarna coklat).

Aroma stik dengan penambahan daging gurita menunjukkan nilai tertinggi pada perlakuan P3 (DG 55\% ) sebesar 7,9 dan nilai terendah pada perlakuan P1 (DG 
$35 \%$ ) sebesar 7,3. Hal ini diduga karena penambahan daging gurita dan tepung meningkatkan nilai aroma stik gurita tetapi tidak memberikan pengaruh nyata dengan kriteria aroma gurita sedikit. Menurut Pratiwi (2013) bahwa semakin banyak jumlah penggunaan tepung ikan, maka aroma pada stik ikan akan semakin nyata dan kualitas juga semakin bagus. Serupa dengan penelitian Muthohar dan Setyanova (2004) bahwa semakin tinggi penambahan ikan tenggiri mampu menimbulkan aroma yang tajam pada produk olahan seperti kerupuk, stik dan amplang. Nilai terendah terdapat pada perlakuan P1 (DG 35\%) sebesar 7,3, diduga karena penambahan daging gurita lebih sedikit dibandingkan dengan perlakuan P2 dan P3. Hal ini diduga aroma daging gurita tertutupi oleh tepung yang digunakan. Menurut Natalia et al. (2018) bahwa dengan penambahan tepung lebih banyak dapat menutupi aroma daging gurita pada produk kerupuk, sehingga aroma daging gurita kurang menonjol atau spesifik.

Aroma stik pada penelitian ini lebih tinggi dari aroma tertinggi produk stik ikan nilem dari hasil penelitian (Iqbal et al., 2016) yaitu $7,1 \%$ dengan penambahan daging ikan nilem $15 \%$ sedangkan untuk daging gurita memiliki warna yang lebih tinggi yaitu 7,9\%, karena semakin banyak telur nilem yang ditambahkan maka aroma dari stik menjadi semakin mengeluarkan aroma dari telur nilem.

Rasa stik dengan penambahan daging gurita menunjukkan nilai tertinggi pada perlakuan P3(DG $55 \%$ ) sebesar 7,6 dan nilai terendah pada perlakuan P1(DG $35 \%$ ) sebesar 6,3. Rasa stik pada penelitian ini lebih tinggi dari rasa tertinggi produk stik ikan nilem dari hasil penelitian (Iqbal et al.,2016) yaitu 7,2\% dengan penambahan daging ikan nilem $15 \%$, sedangkan untuk daging gurita memiliki rasa yang lebih tinggi yaitu 7,6\%.Hal ini diduga karena bertambahnya daging gurita menyebabkan rasa stik yang semakin kuat. Serupa dengan penelitian Natalia et al. (2018) menyatakan bahwa seiring dengan bertambahnya konsentrasi daging gurita yang diberikan semakin kuat rasanya dan menimbulkan rasa gurih pada kerupuk. Rasa yang semakin kuat disebabkan karena kandungan protein yang menimbulkan rasa gurih terhadap olahan yang dihasilkan. Menurut Aryani dan Norhayani (2011) komponen pembentuk rasa bahan pangan berhubungan dengan protein dalam bahan pangan, semakin banyak protein yang terkandung maka produk yang dihasilkan akan terasa semakin gurih. Serupa dengan penelitian yang dilakukan oleh Winarno (1992) dalam Istanti (2005), rasa gurih dapat disebabkan oleh kandungan protein yang terhidrolisis menjadi asam amino yaitu asam glutamat yang menimbulkan rasa khas yang kuat. Nilai terendah terdapat pada perlakuan P1 (DG 35\%) diduga karena penambahan daging gurita lebih sedikit dibandingkan tepung sehingga stik tidak memiliki rasa khas gurita. Hal ini sesuai dengan penelitian yang dilakukan oleh Natalia et al.(2018) menyatakan bahwa rendahnya rasa kerupuk pada daging gurita diduga karen penambahan daging gurita yang sedikit dibandingkan dengan tepung. Menurut Maghfiroh (2000), salah satu faktor yang menentukan produk diterima atau tidak oleh konsumen adalah faktor rasa. Walaupun parameter penilaian yang lain baik, jika rasanya tidak disukai maka produk akan ditolak.

Tekstur stik dengan penambahan daging gurita menunjukkan nilai tertinggi pada perlakuan P1 (DG 35\%) sebesar 6,9, 
dan nilai terendah pada perlakuan P3(DG $55 \%$ ) sebesar 6,6. Nilai tekstur pada perlakuan P3 memiliki nilai yang lebih rendah dibandingkan perlakuan P1 dan P2. Hal ini diduga karena semakin banyak penambahan daging gurita menyebabkan bahan tepung kurang baik menciptakan tekstur stik yang kurang renyah, dimana meningkatnya jumlah air dalam bahan pangan menyebabkan stik teksturnya kurang renyah. Apriliani (2010) menyatakan bahwa keberadaan air dalam suatu produk pangan akan mempengaruhi lunak atau kerasnya suatu produk pada saat digigit dan dikunyah. Tekstur stik pada penelitian ini lebih rendah dari warna tertinggi produk stik ikan nilem dari hasil penelitian (Iqbal, ett al 2016) yaitu $7,2 \%$ dengan penambahan daging ikan nilem $15 \%$ sedangkan untuk daging gurita memiliki warna yang lebih tinggi yaitu $6,7 \%$.Nilai terendah terdapat pada perlakuan P3 (DG 55\%) diduga karena konsentrasi penambahan daging gurita yang semakin banyak yang menyebabkan tekstur stik yang lebih keras, sesuai dengan penelitian Natalia et al. (2018) yang menyatakan bahawa semakin banyak penambahan daging gurita pada kerupuk maka tekstur krupuk akan semakin keras.

\section{Uji Kimia}

Kadar protein stik dengan penambahan daging gurita menunjukkan nilai kadar protein tertinggi pada perlakuan P3 (DG $55 \%$ ) sebesar 32,04, sedangkan nilai terendah pada perlakuan P1 (DG 35\%) sebesar 30,87. Hal ini disebabkan meningkatnya penambahan daging gurita dan tepung terigu maka kadar protein semakin tinggi. Daging gurita sendiri memiliki kandungan protein sekitar 46,98\% (Riyanto et al., 2016), sedangkan kandungan protein pada tepung terigu sekitar 11,80\% (Kent, 1983). Penelitian ini sesuai dengan standar SNI (2000) tentang stik ikan dengan kadar protein minimal 5\%. Kadar protein stik pada penelitian ini lebih tinggi dari kadar protein tertinggi produk stik ikan nilem dari hasil penelitian (Iqbal et al., 2016) yaitu $12,72 \%$ dengan penambahan telur ikan nilem $15 \%$ sedangkan untuk daging gurita memiliki kadar protein yang lebih tinggi yaitu $32,04 \%$.

Penurunan nilai kadar protein pada perlakuan P1 diduga berkurangnya penambahan daging gurita dan tepung, sehingga stik yang dihasilkan memiliki nilai yang rendah. Tinggi atau rendahnya nilai protein yang terukur diduga dipengaruhi oleh besarnya kandungan air yang hilang (dehidrasi) dari bahan. Nilai protein yang terukur akan semakin besar jika jumlah air yang hilang semakin besar (Iqbal et al.,2016). Protein merupakan senyawa yang sangat dibutuhkan oleh tubuh, sehingga kandungan protein dalam bahan pangan menjadi salah satu perhatian khusus. Akan tetapi protein dalam bahan makan sangat mudah mengalami penurunan kadar protein (Winarno, 2008).

Kadar lemak menunjukan perlakuan penambahan daging gurita memberikan pengaruh sangat nyata. Perlakuan P1 dan P2 tidak berpengaruh nyata, tetapi memberikan pengaruh nyata terhadap perlakuan P3. Hal ini diduga semakin bertambahnya daging gurita memiliki kandungan kadar lemak yang tinggi sehingga pada kadar lemak meningkat. Menurut Nova, (2014) menyatakan hasil lemak kerupuk ikan sejalan dengan penambahan daging ikan yang semakin tinggi, semakin tinggi daging ikan yang ditambahkan, maka konsentrasi kandungan lemak akan 
semakin meningkat. Menurut Kurniawati (2013) pengaruh penambahan daging ikan kedalam pengolahan produk kerupuk ikan dapat menambahkan lemak produk tersebut.

Menurut Agustini dan Sawastawati (2014),tingginya kadar lemak disebabkan bahan baku ikan tenggiri yang memiliki kadar air yang rendah. Rahayu et al. (1992) kadar lemak pada stik ikan berbanding terbalik dengan kadar airnya,stik ikan dengan kandungan lemak yang tinggi biasanya mempunyai kandungan air cenderung lebih rendah. Berdasarkan SNI 01-2886-2000, bahwa standar kandungan lemak pada makanan ringan maksimal $30 \%$ untuk yang dimasak tanpa menggunakan minyak dan $38 \%$ untuk makanan ringan yang dimasak menggunakan minyak. Kadar lemak pada penelitian ini lebih rendah dari kadar lemak tertinggi produk stik ikan tenggiri dari hasil penelitian (Yanuar et al., 2016) yaitun $34,89 \%$ Jika dilihat dari batas standar yang diperbolehkan oleh SNI (2000), stik daging gurita masih layak untuk dikonsumsi karena kadarnya lebih rendah dari batas maksimal yang dianjurkan yaitu $38 \%$.

Kadar karbohidrat stik dengan penambahan daging gurita menunjukkan nilai kadar kabohidrat tertinggi pada perlakuan P3 (DG $55 \%$ ) sebesar 7,81, sedangkan nilai terendah pada perlakuan P1 (DG 35\%) sebesar 5,54. Hal ini diduga karena semakin banyaknya penambahan daging gurita dan tepung pada perlakuan P3 semakin banyak sehingga kadar karbohidrat semakin meningkat. Hal ini sesuai dengan penelitian yang dilakukan oleh Natalia $e t$ al. (2018) bahwa penambahan konsentrasi daging gurita dan tepung tapioka maka kadar karbohidrat semakin tinggi. Kandungan karbohidrat pada daging gurita sekitar 31,53\% (Riyanto et al., 2016), sedangkan kandungan karbohidrat pada tepung terigu sekitar $74,5 \%$ (Kent, 1987) dan tepung tapioka sendiri memiliki kandungan karbohidrat sekitar 8,69\%. Serupa dengan penelitian Handayani (1995) bahwa semakin banyak penambahan daging ikan lele pada produk stik maka kadar karbohidrat semakin meningkat. Kadar karbohidrat pada penelitian ini lebih tinggi dari kadar karbohidrat tertinggi produk stik daging ikan kembung dari hasil penelitian (Siswanti, 2016) yaitu 54,30\%.

\section{KESIMPULAN}

1. Terdapat pengaruh penambahan daging gurita terhadap uji organoleptik rasa stik. nilai rerata rasa tertinggi terdapat pada perlakuan P3 yaitu 7,6 sedangkan tidak berpengaruh pada warna, aroma dan tekstur.

2. Terdapat pengaruh penambahan daging gurita terhadap kandungan gizi (proksimat) yaitu kadar lemak dan kadar karbohidrat stik daging gurita. Nilai rerata kadar lemak tertinggi terdapat pada perlakuan P1 yaitu $34,27 \%$, dan kadar karbohidat dengan nilai rerata tertinggi terdapat pada perlakuan P1 yaitu 7,81\%, sedangkan tidak terdapat pengaruh pada kadar air dan kadar protein.

\section{DAFTAR PUSTAKA}

Adawiyah R. 2008. Pengolahan dan Pengawetan Ikan. Bumi Aksara. Jakarta.

Apriliani MW. 2010. Pengaruh penggunaan tepung tapioca dan carboxy methyl cellulose (CMC) pada pembuatan keju mozzarella 
terhadap kualitas fisik dan organoleptik. Skripsi. Fakultas Peternakan. Universitas Brawijaya, Malang.

Aryani, Norhayani. 2011. Pengaruh konsentrasi putih telur ayam ras terhadap kemekaran kerupuk ikan mas (Cyprinus carpio). Journal of Tropical Fisheries. 6(2).

Badan Standarisasi Nasional. 2000. Makanan Ringan Ekstrudat.

Fajriah. 2015. Analisis komoditas unggulan perikanan tangkap kota kendari. Laporan Penelitian Hibah Desentralisasi Dosen Pemula Kemenristek Dikti. Universitas Muhammadiyah Kendari. Kendari.

Food Agriculture Organization 2014. Cephacalopods of the world, an annotated and illustrated catalogue of cephalopod species known to date, Volume 3. Octopods and vampire squid. FAO species Catalogue for Fishery Purposes 4(3): $\quad 1020-8682$.

Handayani W, Ilmingtiyas D. 1995. Stik Lele Alternatif Diversifikasi Olahan Lele (Clarias sp.) Tanpa Limbah Berkalsium Tinggi. Jurnal Ilmiah Serat Acitya. Semarang: UNTAG.

Histifarina D, Musaddad D. 1998. Pengaruh cara pelayuan daun, pengeringan dan daya simpan bawang merah. Jurnal Hortikultura. 8(1): 1036-1047.

Iqbal A, Rochima E, Lis R. 2016. Penambahan telur ikan nilem terhadap tingkat kesukaan produk olahan stik. Perikanan dan Ilmu Kelautan. 7(2): 150-155.
Istanti I. 2005. Pengaruh lama penyimpanan terhadap karakteristik kerupuk ikan sapu-sapu (Hyposarcus pardalis). [Skripsi] Teknologi Hasil Perikanan Institut Teknologi Bogor.

Kent NL. 1983. Technology of Cereal (3rd ed). Sydney: Pergamon Press.

Kasmadiharja H. 2008. Kajian penyimpanan sosis, naget ayam dan daging ayam berbumbu dalam kemasan polipropilen rigid. Skripsi. Fakultas Teknologi Pertanian. Institut Pertanian Bogor. Bogor.

Listiani N. 2013. Penerapan standar ekspor gurita dan ikan teri perusahaan perikanan di Kendari. Buletin Ilmiah Litbang Perdagangan, 7(1).

Natalia D, Ibrahim MN, Isamu KT. 2018. Uji sensori, kimia dan fisik kerupuk gurita dengan penambahan konsentrasi daging gurita (Octopus cyanea) yang berbeda. Jurnal Fish Protech.1(2):102-112

Poedjiadi, Supriyanti. 2005. Dasar-dasar biokimia. Universitas Indonesia Press. Jakarta.

Pratiwi, Fitriana. 2013 Pemanfaatan tepung daging ikan layang untuk pembuatan stik ikan. Skripsi Jurusan Teknologi Jasa Dan Produksi Fakultas Teknik Universitas Negeri Semarang.

Rahayu WP, Ma'oen S, Suliantari, Fardiaz S. 1992. Teknologi fermentasi produk perikanan. Bogor: PAU, Pangan dan Gizi IPB Bogor. 
Riyanto B, Trilaksani W, Lestari R. 2016. Minuman nutrisi olahraga berbasis hidrolisat protein gurita. Jurnal Pengolahan Hasil Perikanan Indonesia.19(3): 339-347.

Steel RGD, Torrie JH. 1993. Prinsip dan Prosedur Statistika. Jakarta: Penerbit PT. Gramedia Pustaka Utama.

Yanuar V, Suharjo M, Abjudelmen I. 2016. Pengaruh bahan baku ikan terhadap nilai organoleptik dan nilai kandungan gizi produk stik ikan di Kabupaten Kotawaringin Barat. [Jurnal] 41(3): 346-354.

Zulfahmi AN, Swastawati F, Romadhon. 2014. Pemanfaatan daging ikan tenggiri (Scomberomorus commersoni) dengan konsentrasi yang berbeda pada pembuatan kerupuk ikan. Pengolahan dan Bioteknologi Hasil Perikanan. 3(4): 133-139. 